\title{
TRÊS TESES MEMORÁVEIS EM MINHA VIDA $\left({ }^{\star}\right)$.
}

Educado dentro dos rígidos princípios de respeito à verdade custe o que custar, tive ensejo, em minha já dilatada existência de estudioso de problemas culturais brasileiros, de defender três pontos de vista em franco antagonismo com idéias firmadas de longa data, embora sem base sólida, mas acatadas por grande número de adeptos. Dêsses embates, que me custaram canseiras, dissabores e até prejuízos de vária ordem, saí vitorioso sempre, por manter-me intransigentemente fiel às minhas convicções, calcadas naquilo que me parecia, e era, com efeito, acertado.

A primeira vez em que tal sucedeu, há, precisamente, 7 lustros decorridos. Era então estudante de Medicina e estava a cursar o penúltimo ano acadêmico. Senão quando, irrompeu na capital baiana violenta epidemia de febre tifóide. O pânico estabelecido e o desencôntro de opinióes acêrca das origens do flagelo, levaram-me a procurar por mim mesmo o caminho certo a trilhar, em defesa do próprio eu. E desde logo me surgiu a idéia de tomar o assunto para ponto de minha tese do doutorado. À medida que meus conhecimentos progrediam na matéria e que minhas observações se acumulavam em tôrno da epidemiologia do mal, topava pela frente coisas desconcertantes. Assim, por exemplo, chegava a conclusões diametralmente opostas ao que era consenso unânime da classe médica local, inclúsive de vozes as mais conspícuas. Rotulada a princípio, pelas próprias autoridades sanitárias, de paratifose, não passava a doença grassante da genuína febre tifóide, causada pelo bacilo de Eberth-Gaffky, morbo de cuja não existência naquele meio se tinha arraigada convicção geral. E não foram os peixes larvófagos distribuídos pela Comissão Anti-Amarílica da Rockefeller os disseminadores da epidemia, como de comêço se supôs $\epsilon$ proclamou, mas a água inquinada do açude do Queimado, da-

(*). - Palavras pronunciadas pelo Dr. Edgard de Cerqueira Falcão, no ato da entrega, a 16 de março de 1960, da Medalha de Ouro - "Prêtmio Sociedade Paulista de História da Medicina", que the foi outorgada em atenção ao seu trabalho "Pirajá da Silvá; sua vida e sua obra" (Nota da Redação). 
da a beber à população in natura, após receber fortes enxurradas que a toldaram sobremaneira. Pior do que tudo, depararamse a mim procedimentos desonestos em matéria de diagnóstico $\mathrm{rla}$ infecção e vieram ter às minhas mãos provas concretas de tais incorreções. Fiquei num dilema: ou exibir semelhantes provas e, com isso, acarretar tremenda onda de animosidade contra mim, inclusive entre os que iam argüir e julgar meu trabalho, ou silenciar, deixando campear o êrro premeditado. Não tive dúvida: optei pela primeira alternativa $€$ arrostei impàvidamente a ira dos meus argüidores. No dia 17 de março de 1926, defendi solenemente minha tese para o doutorado, a versar sôbre "A Febre Tifóide na Cidade do Salvador". Com ela provei que só a eberthose genuína grassava na minha cidade natal, inexistindo as paratifóides ou sendo casos excepcionais. A banca examinadora, composta de dois professôres adversários e de um amigo, acabou por aprovar-me com distinção, após seis horas de renhida discussão em que não deixei passar um item sem resposta adeqüada, inclusive exibindo provas materiais de minhas afirmações categóricas. O tempo correu e a realidade soberana triunfou: hoje, na Bahia, a classe médica já admite que só a febre tifóide é freqüente por lá, constituindo as paratifóides casos esporádicos e isolados. Aliás, essa verdade vale para todos os demais rincões do Brasil, inclusive para a capital bandeirante, onde o mais recente estudo publicado, na "Revista do Instituto de Medicina Tropical de São Paulo" (Vol. I, n. 3, setembro-outubro, 1959 , págs. 183-184), consigna $97,4 \%$ e $98 \%$ de casos bacteriològicamente analisados, nos períodos $1948-$ 1957 e 1934-1943 respectivamente, como sendo devidos exclusivamente ao b. de Eberth-Gaffky.

A segunda tese ruidosa, por mim defendida, relacionou-se com a fundação da Cidade do Salvador. Problema considerado sem solução pelos historiadores brasileiros, e sobretudo pelos baianos, que chegaram a criar certa data simbólica para as comemorações do quarto centenário, transcorrido em 1949, desenhou-se a fundação em aprêço claramente perante os meus olhos, ao ler com a devida atenção os documentos coevos. E não tive receio de lançar de público a minha interpretação, que Łixava em $10^{\circ}$ de maio de 1549 o comêço da existência oficial da primitiva capital brasileira. Nova onda de adversários se elevou contra meu ponto de vista. Instado pelo saudoso Prof. Braz do Amaral, e, na qualidade de convidado de honra, compareci ao I Congresso de História da Bahia, em março de 1949, sobraçando a tese "O estabelecimento da Cidade do Salvador na Bahia de Todos os Santos em 1549 - O predicamento de cida- 
de". Impotente para destruir lealmente minhas criteriosas deduções, apelou a legião de meus antagonistas na questão, para tôda a sorte de indignidades. Reagindo à altura, consegui manter inflexível meu raciocínio lógico, a aguardar que futuros juízes, isentos de paixão, possam dizer a última palavra.

Da terceira vez que tomei sôbre os ombros o encargo de demonstrar uma verdade científica, fí-lo com o mesmo entusiasmo das ocasiões anteriores. Começou a campanha em 1951, perante o Primeiro Congresso Brasileiro de História da Medicisa, reunido no Rio de Janeiro, em julho daquele ano. Apresentei o problema da determinação da especificidade do Schistosoma mansoni, apontando a figura do Prof. Pirajá da Silva como árbitro da célebre pendência em tôrno do assunto, no início dêste século. Pouco depois, contestaram-me a afirmação, dizendo que o parasitologista brasileiro fizera a descrição do famoso trematóide com atraso de dois anos em relação ao seu colega inglês, Sambon, e que, por isso, deixou de conquistar para - Brasil grande e imarcescível glória. Tomei o claro desafio ao pé da letra, e tratei de provar o contrário. Consegui fazê-lo de tal maneira que o mundo científico ficou todo do meu lado. As maiores autoridades estrangeiras em Medicina Tropical, verbi gratia Philip Manson-Bahr, de Londres, e a plêiade de colaboradores do "Tropeninstitut" de Hamburgo, chefiada por Ernst Nauck, espontâneamente se declararam a meu favor, reconhecendo a prioridade brasileira na descrição e identificação do S. mansoni. Três livros vim a publicar, enfeixando a vida e a obra do Prof. Pirajá da Silva. E' a êste conjunto que a Sociedade Paulista de História da Medicina acaba de premiar, conferindo-me a medalha de ouro que leva o seu nome. Há 34 anos passados, deixei de receber outra medalha de ouro, o Prêmio Alfredo Brito, pelo meu amor e intransigência para com uma verdade científica. A Congregação da Faculdade de $\mathrm{Me}$ dicina da Bahia, ao ter que emitir decisão a respeito, em 1927, se dividiu e não chegou a votar a concessão da láurea, adiando sine die a discussão. Hoje, transcorrida essa longa etapa, vejo finalmente reconhecido o mérito dos meus esforços, no sentido de sustentar sem desfalecimento a verdade acima de tudo. Perdi naquela época um honroso galardão, mas agora recebo outro de não menor monta. Valeu a pena esperar e perseverar no culto da honestidade científica.

Dr. EDGARD DE CERQUEIRA FALCão 